\title{
Assessment of the essential attributes of Primary Health Care for children
}

\author{
Avaliação dos atributos essenciais da Atenção Primária à Saúde da criança \\ Evaluación de los atributos esenciales de la Atención Primaria a la Salud del Niño
}

\author{
Juliane Pagliari Araujo', Cláudia Silveira Viera", Beatriz Rosana Gonçalves de Oliveira", \\ Maria Aparecida Gaiva"I", Rosa Maria Rodrigues" \\ 'Instituto Federal do Paraná. Londrina, Paraná, Brazil. \\ "Universidade Estadual do Oeste do Paraná. Cascavel, Paraná, Brazil. \\ II' Universidade Federal do Mato Grosso. Cuiabá, Mato Grosso, Brazil.
}

\section{How to cite this article:}

Araujo JP, Viera CS, Oliveira BRG, Gaiva MA, Rodrigues RM. Assessment of the essential attributes of Primary Health Care for children. Rev Bras Enferm [Internet]. 2018;71(Suppl 3):1366-72. [Thematic Issue:

Health of woman and child] DOI: http://dx.doi.org/10.1590/0034-7167-2017-0569

Submission: 08-06-2017 Approval: 11-09-2017

\begin{abstract}
Objective: To identify the presence and extent of essential attributes in primary health care services for children, focusing on the evaluation of structure and process. Method: Evaluative, quantitative study carried out in 23 traditional basic health units in a city in Parana State, with 548 caregivers of children under 12 years old, using the Primary Care Assessment Instrument (PCATool Brazil), child version. Essential and general scores of the primary care were calculated according to the methodology proposed, with a cut-off score $\geq 6.6$. Results: The scores of the essential attributes in relation to structure are: Accessibility (5.5), Kinship (6.9), Integrality of care - Services Available (6.0) and Coordination - System information (7.4). As for the Process, the following results were obtained: First visit - Use (8.6), Longitudinally (6.1), Integrality - Services Provided (6.1) and Coordination - Integration of Care (6.9). Conclusion: The essential score was 6.6 and the general score was 6.3 , showing weak focus on primary health care.
\end{abstract}

Descriptors: Primary Health Care; Child Health; Health Management; Quality of Health Care; Pediatric Nursing.

\section{RESUMO}

Objetivo: Identificar presença e extensão dos atributos essenciais em serviços de atenção primária à saúde da criança com enfoque na avaliação de estrutura e processo. Método: Estudo avaliativo, quantitativo, realizado em 23 unidades básicas de saúde tradicionais, em município do Paraná, com 548 cuidadores de crianças menores de 12 anos, utilizando o Instrumento de Avaliação da Atenção Primária (PCATool Brasil), versão criança. Escores essencial e geral da atenção primária foram calculados seguindo a metodologia proposta para tal, com ponto de corte $\geq 6,6$. Resultados: Os escores dos atributos essenciais em relação à estrutura são: Acessibilidade $(5,5)$, Grau de afiliação $(6,9)$, Integralidade - Serviços Disponíveis $(6,0)$ e Coordenação Sistema de informação $(7,4)$. Quanto ao Processo, resultaram: Acesso de Primeiro Contato - Utilização $(8,6)$, Longitudinalidade $(6,1)$, Integralidade - Serviços Prestados $(6,1)$ e Coordenação - Integração dos Cuidados $(6,9)$. Conclusão: O escore essencial foi 6,6 e o geral 6,3, evidenciando fraca orientação para atenção primária à saúde.

Descritores: Atenção Primária à Saúde; Saúde da Criança; Gestão em Saúde; Qualidade da Assistência à Saúde; Enfermagem Pediátrica.

\section{RESUMEN}

Objetivo: Identificar la presencia y la extensión de los atributos esenciales en los servicios de atención primaria a la salud del niño, con enfoque en la evaluación de la estructura y el proceso. Método: Se trata de un estudio evaluativo, cuantitativo, realizado en 23 unidades básicas de salud tradicionales del municipio de Paraná, entre 548 cuidadores de niños menores de 12 años, utilizando el Instrumento de Evaluación PCATool Brasil, versión para niños. Las puntuaciones iniciales y generales de la atención primaria se calcularon siguiendo la metodología propuesta, con punto de corte $\geq 6,6$. Resultados: 
Las puntuaciones de los atributos esenciales con relación a la estructura son: Accesibilidad $(5,5)$, Grado de afiliación $(6,9)$, Integralidad - Servicios Disponibles $(6,0)$ y Coordinación - Sistema de información $(7,4)$. En cuanto al Proceso, se encuentran: Acceso de Primer Contacto - Utilización $(8,6)$, Longitudinalidad $(6,1)$, Integralidad - Servicios Prestados $(6,1)$ y Coordinación - Integración de los Cuidados (6,9). Conclusión: La puntuación principal fue de 6,6 y la general, 6,3, demostrando una orientación precaria de la atención primaria a la salud.

Descriptores: Atención Primaria a la Salud; Salud del Niño; Gestión en Salud; Calidad de la Asistencia a la Salud; Enfermería Pediátrica.

\section{CORRESPONDING AUTHOR Claudia Silveira Viera E-mail: clausviera@gmail.com}

\section{INTRODUCTION}

In the search for a paradigm shift in actions and thinking about health, since the International Conference on Primary Health Care held in 1978 ${ }^{(1)}$, Primary Health Care (PHC) has been gaining prominence, with a view to invest in a new health policy. In this context, a renewal of PHC is discussed, with the objectives of preparing services for new challenges, improving the quality of health care and expanding countries' capacity to develop a coordinated, effective and sustainable strategy to address health problems $\mathrm{s}^{(2)}$.

PHC can be understood as the level of care that represents the entrance door to the health system. PHC services provide care to the person over time, dealing with the most common problems of the community through health promotion, prevention, treatment and rehabilitation ${ }^{(3)}$.

For the health service to be focused on PHC, it must effectively present essential attributes, which are first-visit care, longitudinality, Integrality of care and coordination, and derived attributes, which are family and community orientation and cultural competence ${ }^{(3)}$. These attributes make up for a PHC that can organize the health system and coordinate care, fulfilling the three essential functions of this level of care: communication, accountability and problemsolving capacity ${ }^{(4)}$.

With these characteristics present and developed in an active and effective way, a PHC service should solve around $85 \%$ of health problems ${ }^{(3)}$. In Brazil, PHC is based on the principles of the Unified Health System (SUS), implemented through the Family Health Strategy (FHS).

Child care in PHC services, which is the focus of the discussion in this study, still presents a low resoluteness capacity, which is based on biomedical care and is fragmented and focused on assistance to acute diseases and spontaneous demands. Despite the transformations in health policies and guidelines directed at children, the scenario of child morbidity and mortality reveals a lack of articulation and Integrality of care, shown through the high rates of preventable child mortality $(66.56 \%)$ and hospitalizations for preventable conditions $(65.2 \%)^{(5-9)}$.

\section{OBJECTIVE}

To identify the presence and extent of the essential attributes of primary health care services for children, focusing on the evaluation of the structure and the process in the perception of caregivers.

\section{METHOD}

\section{Ethical aspects}

The study followed the ethical precepts necessary for the development of research with human beings and was approved by the Research Ethics Committee of the State University of Western Paraná.

\section{Design, setting and study dates}

The present study has a quantitative and evaluative approach and is part of a multicentric project developed in the states of Paraná and Paraíba. The data presented here refer to the study developed in $24 \mathrm{PHC}$ units in a city in the countryside of the state of Paraná. At the time of data collection, 23 of these units were Basic Health Units (BHU) and one had two family health strategy teams (FHS). The research was conducted from June 2012 to November 2013.

The Donabedian model ${ }^{(10)}$ was one of the frameworks used for evaluating the healthcare systems. This model proposes an analysis of the structure, process and outcomes of health services, each being equally important and having complementary characteristics, which should be used to evaluate health actions ${ }^{(11)}$.

In this model ${ }^{(10)}$, structure is defined as the place where care occurs, that is, the resources needed for the care process, including material, human resources and the organizational structure of the service ${ }^{(10)}$. The process corresponds to the activities taken by the health team to provide assistance to the user. It is measured according to the quality standards established by the respective services and professions, including technical components and interpersonal relations. Outcomes are understood as changes in health care results, including the level of satisfaction, health status, inclusion of the users and their knowledge about their health, among others ${ }^{(10-11)}$. Based on this evaluation model, Starfield and colleagues developed a PHC assessment tool called Primary Care Assessment Tool - PCAToo/ ${ }^{(12)}$. The PCATool is an instrument that has had good performance assessing PHC attributes and is able to measure aspects of the health service's structure and process. The validated version in Brazil consists of 55 Likert-type questions, with scores varying from 1 to 4 for each element that composes the attribute: certainly yes (4); probably yes (3); probably not (2); certainly not (1).

The PCATool assembles the dimensions structure and process and includes: a) structure: longitudinality - kinship; first visit - accessibility; coordination - System information; Integrality of care - services available; b) process: first visit - use; longitudinality; coordination - integration of care; Integrality of care - services provided. The data collection in the present 
research used the Instrument of Primary Care Evaluation PCATool-Brasil, child version ${ }^{(13)}$.

\section{Population or sample}

The study subjects were caregivers/relatives of children under 12 years old who were treated at the PHC units of the city under study, selected among the users of the service who had had at least two visits in the six months prior to the day of data collection. Inclusion criteria were: residing in an urban area; being able to answer the form (ability to understand, express and comprehend the documents presented); being the main caregiver of the child; knowing the unit they evaluated; and the child being under twelve years old. Respondents residing outside the area of the hospital, but using that service by choice, were included.

For the sample calculation, the research was first carried out in the registries of the health units to assess the number of visits of children under 12 years of age during the last six months. The source of information was originated in TABWIN with the reports of procedures performed in the city in children up to twelve years old, comprising 34,369 visits. From this data, the simple stratified random probabilistic sample was calculated with proportional share per unit estimated in 548 participants.

The stratified sample was defined according to the statistical calculation ${ }^{(14)}$ :

$$
\begin{aligned}
\frac{N_{h}}{N}=\frac{n_{h}}{n} \text { onde: } & N_{h} \text { : population stratum } \\
& N \text { : population } \\
& n_{h} \text { : sample stratum } \\
& n: \text { sample. }
\end{aligned}
$$

The margin of error was calculated with $\alpha$ level of $5 \%$. A margin of error of $5 \%$ with a $95 \%$ confidence interval was adopted to obtain the sample of relatives/caregivers to be interviewed.

\section{Study protocol}

For data collection, the children's caregivers were selected by systematic sampling in the waiting list for medical or nursing care, between October 2012 and February 2013. The instruments were applied by undergraduate nursing and medicine students, previously trained by the research team. The researchers approached caregivers and explained the purpose of the research, inviting them to participate. If there was an agreement, the Consent Form was read and requested to be signed. The form was completed by the data collector, according to the orientation of the instrument manual ${ }^{(13)}$.

\section{Analysis of results and statistics}

The forms were typed into an Excel database, with double entry and data checking for greater reliability. The SPSS 17.0 software was used to analyze the data, and the descriptive statistical analysis was performed through the calculation of the mean, standard error, minimum and maximum. For the score of the component "kinship", the following algorithm ${ }^{(13)}$ was used:
1. All answers $\mathrm{NO}: \mathrm{A} 1=\mathrm{A} 2=\mathrm{A} 3=0$, kinship $=1$;

2. One, two or three answers YES, but different: $\mathrm{A} 1 \neq \mathrm{A} 2 \neq \mathrm{A} 3 \neq 0$, kinship $=2$;

3. Two equal answers $Y E S$, regarding the same service: $\mathrm{A} 1=\mathrm{A} 2$ or $\mathrm{A} 1=\mathrm{A} 3$ or $\mathrm{A} 2=\mathrm{A} 3$, kinship $=3$;

4. All answers $Y E S$ and regarding the same service: $\mathrm{A} 1=\mathrm{A} 2=\mathrm{A} 3=1$, kinship $=4$.

The essential score of the PHC was obtained by the mean of the items of each element composing the attribute and the general means of these attributes. The value obtained was converted into a scale of $0-10$ (score obtained-1) $\times 10 / 3^{(13)}$. The general score of the PHC was obtained by the mean of the scores of all PHC attributes divided by the number of attributes $((\mathrm{A}+\mathrm{B}+\mathrm{C}+\mathrm{D}+\mathrm{E}+\mathrm{F}+\mathrm{G}+\mathrm{H}+\mathrm{I}+\mathrm{J}) / 10)$. In order to compare the presence and extent of the attributes, the cut-off scores were $\geq 6.6$, defined as high, and $<6.6$, defined as low/unsatisfactory ${ }^{(13)}$.

\section{RESULTS}

Table 1 presents the data regarding the characterization of the subjects participating in the study. In $440(80.29 \%)$ of the families, the main caregiver was the mother, $252(45.99 \%)$ had 10 to 14 years of education, $228(41.61 \%)$ had only one child and $297(54.20 \%)$ of the families had their own home.

Table 2 shows the essential score of the PHC (6.6), which obtained a satisfactory value in the caregivers' evaluation, as it was exactly the minimum satisfactory value, represented by the cut-off score for a positive evaluation of the PHC. However,

Table 1 - Characterization of the families of children under 12 years of age attended in primary health care services, Cascavel, Paraná, Brazil, $2013, N=548$

\begin{tabular}{lccc}
\hline Variable & Description & $\mathbf{n}$ & $\mathbf{\%}$ \\
\hline Main caregiver & Mother & 440 & 80.29 \\
& Father & 13 & 2.37 \\
& Grandparents & 54 & 9.85 \\
Years of education of the main caregiver & Others & 41 & 7.46 \\
& 0 to 4 years & 51 & 9.31 \\
& 5 a 9 years & 205 & 37.41 \\
Number of children in the family & 10 a 14 years & 252 & 45.99 \\
& 15 years or more & 14 & 2.55 \\
& Couldn't inform & 26 & 4.74 \\
Family income & One & 228 & 41.61 \\
& Two & 189 & 34.49 \\
& Three & 82 & 14.96 \\
& Four or more & 58 & 8.75 \\
& Not informed/doesn't know & 1 & 0.18 \\
& Less than one MW & 14 & 2.55 \\
& One MW & 118 & 21.53 \\
& Two MW & 202 & 36.86 \\
Type of residence & Three MW & 129 & 23.54 \\
& More than three MW & 79 & 14.41 \\
No income & 1 & 0.18 \\
& Couldn't inform & 5 & 0.90 \\
& Owned & 297 & 54.20 \\
& Rented & 182 & 33.21 \\
& Donated & 68 & 12.41 \\
& Illegal invasion & 1 & 0.18 \\
\hline
\end{tabular}

Note: ${ }^{*}$ Minimum wage $(\mathrm{MW})$ at the time of data collection: $R \$ 678.00$. 
Table 2 - Essential and derived attributes of Primary Health Care services (PHC) in the city of Cascavel, Paraná, Brasil, 2013

\begin{tabular}{lcccc}
\hline \multicolumn{1}{c}{ Essencial Attributes } & \multicolumn{3}{c}{ PHC* Services (N= 548) } \\
\multicolumn{1}{c}{ MS** } & SD*** & Minimum & Maximum \\
\hline Structure & & & & \\
$\quad$ First Visit - Accessibility & 5.5 & 0.131 & 0 & 10 \\
$\quad$ Kinship & 6.9 & 0.128 & 0 & 10 \\
$\quad$ Integrality of care - Services Available & 6.0 & 0.112 & 0 & 10 \\
$\quad$ Coordination - System information & 7.4 & 0.090 & 0 & 10 \\
Process & & & & \\
First Visit - Use & 8.6 & 0.135 & 1.1 & 10 \\
$\quad$ Longitudinality & 6.1 & 0.125 & 3.3 & 10 \\
$\quad$ Integrality of care - Services Provided & 6.1 & 0.302 & 0 & 10 \\
$\quad$ Coordination - Integration of Care & 6.9 & 0.275 & 0 & 10 \\
$\quad$ Essential Score of the PHC* & 6.6 & 0.524 & 2.12 & 10 \\
Derived Attributes & & & & \\
$\quad$ Family orientation & 4.4 & 3.168 & 0 & 10 \\
$\quad$ Community orientation & 5.1 & 3.301 & 0 & 10 \\
$\quad$ General score of the PHC* & 6.3 & 0.581 & 2.48 & 10 \\
\hline
\end{tabular}

Note: *Primary Health Care; ${ }^{* *}$ Mean Score, values converted $(0-10) ; * *$ Standard Error. studies $^{(17-18)}$. It should be noted that the structure has an effect on the care process and, therefore, they complement each other. If one of them presents fragility, as occurred in this study, it may compromise the entire result of the attribute of first visit. Consequently, the fragility of access in health services may compromise all other attributes.

Guaranteeing universal access to children in quality health services can increase the resoluteness capacity of health care, which contributes to addressing acute and chronic health problems ${ }^{(4)}$, linking health promotion and disease prevention. An important tool to increase access for children and their family to $\mathrm{PHC}$ services is the reception, a

the general PHC score was 6.3, demonstrating that the health services evaluated do not provide attributes in their full extent.

Regarding the structure, the first visit - accessibility was the attribute that obtained the lowest mean score (5.5), while the coordination had the highest score (7.4). Regarding the process, the attributes with the lowest scores were longitudinality and Integrality of care (6.1). The first visit - use obtained a mean score of 8.6, indicating users' satisfaction with this attribute (Table 2).

\section{DISCUSSION}

The attribute first visit in the instrument PCATool is divided in structure - accessibility and process - use. The questions about accessibility are related to the care of the child on the same day of illness, waiting time, easy scheduling and telephone counseling ${ }^{(13)}$. In the evaluation of accessibility, the mean score 5.5 indicates a fragility in the structure of the services, which may be related to the lack or low qualification of human resources, lack of equipment, difficulties in scheduling visits, waiting time greater than 30 minutes and inadequate physical space, generating physical barriers to accessibility. A study conducted with children under one year old in family health units in the countryside of São Paulo using the same instrument found satisfactory values of accessibility, since the appointments were previously scheduled and the wait was not longer than 30 minutes ${ }^{(14)}$, different from the present study. However, other studies ${ }^{(15-16)}$ indicate that there are barriers to the access of children in PHC services structured in traditional BHUs.

Regarding the attribute use, the instrument asks if the family seeks the health service due to the child's illness or for revision visits, as well as whether the PHC service refers the patients to specialists $^{(13)}$. The mean score found was 8.6, which shows an effective interrelation between care provider and receiver, leading to user satisfaction in the dynamics of health care (process). Positive results regarding the process were also found in other facilitator of the care process that, when articulated with other tools, can contribute to improve the other attributes of $\mathrm{PHC}$.

The attribute longitudinality in the structure was evaluated by the kinship of the health services studied. This analysis considered the existence of a health service where caregivers frequently take children when they are sick and where a health professional knows the child well. The instrument and also assessed which service or health professional assumes the responsibility for the child's care ${ }^{(13)}$. In the services evaluated, in the traditional health units, the kinship had a mean score of 6.9 , above the cut-off score (6.6). The structure of care in this same attribute was well evaluated in the services studied, which is in consonance with other studies ${ }^{(19-2)}$. In this element of the attribute longitudinality there were no differences regarding the care model. However, the aforementioned studies indicate that the demand for the health service occurs even if the mothers are dissatisfied with the care, distrust the professional's competence and have no bond with the unit, because they have no other option of care.

For longitudinality to be effective and health services focused on PHC, the bond or affiliation between the child's family and the health service must occur. However, despite the good results found in this study, the bond is often established with a single health professional (nurses or physicians). This practice leads to a care with low resoluteness capacity and based on fragmented actions, which reflect in the evaluation of the process of this attribute, which had a non-satisfactory result (mean score 6.1).

The evaluation of the longitudinality process covers the follow-up of the child by the same health professional over a period of time, the professionals' knowledge about the child's clinical history, the communication between the health professional and the mother, and the professional's knowledge about the child's family ${ }^{(13)}$. The aspects that presented unsatisfactory means were related to the professionals' knowledge 
about the most important health problems to the child's family, the work activities of the family members and the professionals' interest in knowing if the family would have difficulties obtaining or paying for the medication. Longitudinality was perceived as not effective, since health professionals do not extend care to the family, with a weak family orientation.

If the professionals know the children's health history and create a bond with the family, it can strengthen longitudinality and improve resoluteness capacity of the service, consequently increasing the satisfaction of the user with the health service and of the professionals with the work performed. It is essential to strengthen the longitudinality of PHC services, since other attributes of the PHC, such as accessibility, family and community orientation, also gain strength when the family already has a bond with the service. In addition, accessibility is a condition for longitudinality to occur. The presence of a bond between family/child and the health service has the additional advantage of making the attribute of Integrality of care easier to be met $^{(23)}$.

The health care model is directly related to longitudinality and to the presence of FHS principles, that is, when this care model is properly implemented it favors longitudinality and increases resoluteness capacity in primary care, reducing costs and improving the quality of care ${ }^{(22)}$. However, the PHC service is only effective when all the attributes are present in their full extension.

Another attribute evaluated was Integrality of care, which included services available (structure) and services provided (process). Regarding Integrality of care, the services must be based on the health needs of the population and available at all times, regardless of the difficulties of the services ${ }^{(3)}$.

In the evaluation of the Integrality of care structure, the questions are related to the set of services available at the $\mathrm{PHC}$, such as: immunization, counseling and treatment of visual problems, family planning counseling, dietary supplementation programs, sutures, actions for drug use and mental health problems, HIV counseling and testing ${ }^{(13)}$.

The mean score (6.0) of the Integrality of care structure was unsatisfactory, a result similar to that presented in other studies $^{(14-17)}$. This reality demonstrates the need for PHC to expand the services offered, addressing the basic health needs of the children and their families and providing care such as orientation and management of common conditions that have considerable impact on the health of families and community, such as alcoholism and drug use. The absence of this structure may lead to poor quality of care; however, adequate structure does not necessarily imply high quality, indicating only a potential for its existence.

In the assessment of the Integrality of care process, the questions are related to orientations on how to keep the child's health, growth, development and safety ${ }^{(13)}$. The mean score of 6.1 indicates that the process of Integrality of care was considered unsatisfactory by the caregivers. Child care at PHC should be guided by strategies focused on comprehensive and expanded care for health promotion and disease prevention. The structure and process of the Integrality of care attribute did not reach the cut-off score (6.6) to be considered satisfactory, demonstrating a low effectiveness of PHC in the reality studied.
The coordination of care, which involves the System information (structure) and the integration of care (process), was satisfactory in this evaluation, representing the attribute best evaluated by caregivers. The element System information is composed of three questions regarding information about children's clinical records and other records, such as the child's book and the parents' knowledge about the medical records. The mean score 7.4 demonstrate users' satisfaction with the structure of the coordination attribute. In order for coordination to be effective, the PHC service must perform three essential functions: organization of flow through the different areas of attention, accountability for users' health and monitoring at any level of health care, and resolution of the population's problems within the health system ${ }^{(13)}$.

In turn, the attribute coordination - integration of care includes referrals of children for consultation with specialists or specialized services, as well as the involvement of the PHC service with these referrals. The mean score 6.9 indicates that this attribute was considered satisfactory by the users. Effective communication between PHC services and specialized services is one of the requirements for an effective coordination of care, which should be understood as a methodology to expand strategies and integrate elements into organizational structures ${ }^{(24)}$.

The coordination of care must possess and provide information regarding the health problems and the services already provided before the current visit ${ }^{(3)}$. It should be noted that in this study the isolated analysis of the coordination attribute showed a satisfactory score. However, despite this result, the coordination of PHC in the city studied still needs to be strengthened. The challenges of the PHC in the city studied are improving the quality of the information in the medical records, using electronic medical records in all the health services, implementing attention networks to optimize access and use of the other health resources of the network and strengthening the mechanisms of communication (referral and counter-referral) ${ }^{(24)}$.

Furthermore, in order to be able to coordinate the health system, the PHC must articulate all its attributes in order to solve most of the population's health problems in a timely manner and ensuring accessibility, continuity of care and accountability with the therapeutic plan. This consideration should be highlighted, since in the essential score obtained of 6.6 is the same as that established for the cut-off score by the authors of the evaluation instrument. In turn, the general score, which considers the focus of care in the family and in the community, was below this value (6.3). This is justified by the fact that the PHC services of the city studied did not have units with family health strategy.

Thus, it is necessary to change the current model of care and to expand the family health teams. In addition, it is essential to structure these teams and to discuss within them the concepts of health and disease, social determinants of disease and work process centered on the family and on the PHC guidelines ${ }^{(25)}$. These transformations are possible based on a change in the care model: the focus of care must be beyond biological, encompassing family care and community participation in promotion and prevention actions.

The findings show that the essential score of the PHC was below the cut-off value, indicating that the health services 
evaluated do not provide the essential attributes in their total extent, which shows a weak focus on primary health care.

The presence and integration of the structure and process of the essential attributes is fundamental for the effectiveness of the services and their focus on PHC. The evaluation and comparison of the structure and process, in the context of the needs of the child population, can broaden the perception that the organization of health services, as well as the process of care, must be changed in order for the outcomes of PHC to be effective and final.

The commitment of the interdisciplinary team and the health managers is essential for the implementation of already existing policies, such as the consolidation and expansion of the FHTs, which insert in their practice the models of innovation and restructuring already elaborated by the Ministry of Health, such as attention networks, an expanded concept of the health-disease process and teamwork with a focus on health promotion.

These results present limitations, since they only assessed the caregivers' point of view. It is necessary to expand the research to other social actors, such as health professionals and managers. Another limitation refers to the fact that the sample of services did not include family health units and was carried out in a medium-sized city in the southern region of the country. Therefore, the generalization of results should be cautious. However, the feedback of the results to the services can serve as an alert for professionals working with children and $\mathrm{PHC}$ managers, contributing to the qualification of these services and generating investments in other research on the subject, considering its relevance to the care of the child.

\section{Limitation of the study}

The study was carried out with caregivers of children attending PHC services in the city. In this sense, the results must be taken from this point of view, which can be expanded with studies in the same reality but from the perspective of professionals and managers. Thus, it would be possible to obtain a full understanding of the child's health care.

\section{Contributions to the area of nursing, health or public policy}

Primary Health Care is based on health care system that should assumes and offer care to all segments of the population in its territory, promoting their insertion in health services and assuming responsibility for the continuity of care throughout their lives. However, the effectiveness of the health care provided by this sphere requires some elements for the operationalization of a resoluteness of care. For this, it is important to recognize the extent of these attributes and understand how PHC is characterized. Thus, this study contributes to the necessary reflection on the results of the evaluation of the health services by the actors involved in the process, which should be consider as a strategy to recognize the problems that keep these services from being effective and find ways to reorganize the current model of care and the work process in health.

Nursing is the professional group with expressive performance in PHC, as it is the propeller of many actions developed in this level of care. The evaluation of the process and structure of the PHC shows that the provision of this service must be organized based on the healthcare team and centered on the user, contrary to the findings that show that the work process is centered in a single professional, the physician. To that end, nurses and their staff are key elements in the reorganization of the work process, changing it from physician-centered to a process with planned demand, done with teamwork and using the soft and hard technology tools available to this professional group. This will contribute to the resolution of many of the access problems faced by PHC users.

\section{CONCLUSION}

The evaluation of health services is an initiative for further progress in reshaping care and changing the work process. The PCATool Brazil child version used in this study is an adequate tool for evaluation and comparison of the structure and process of PHC services. The scores evidenced by the evaluation instrument showed weak focus on primary health care in the city studied.

Among the attributes evaluated, there was a low level of user satisfaction regarding first visit - accessibility and Integrality of care - available services. Therefore, despite the fact that $\mathrm{PHC}$ is the preferred entrance door for the health system, the assessment of its empirical reality shows that it is necessary to change the organization of the work process and the services offered, which are currently focused on intervention at the moment of disease, promoting an assistance model that articulates all attributes of Primary Health Care.

\section{FUNDING}

Research developed with the support of the National Council for Scientific and Technological Development.

\section{REFERENCES}

1. World Health Organization - WHO. The World Health Report 2008: primary health care now more than ever. WHO; 2008.

2. Paim JS. A constituição cidadã e os 25 anos do Sistema Único de Saúde (SUS). Cad Saúde Pública [Internet]. 2013 [cited 2017 Oct 20];29(10). Available from: http://www.scielo.br/pdf/csp/v29n10/a03v29n10.pdf

3. Starfield B. Atenção primária: equilíbrio entre necessidades de saúde, serviços e tecnologia. Brasília, DF: UNESCO, MS; 2002.

4. Mendes EV. A construção social da atenção primária à saúde. Brasília: CONASS; 2015.

5. Simões MA, Pabis FC, Freitas AKE, Watanabe PK, Kayano RM, Noronha L. Preventable causes of death and factors associated with newborn survival at a university hospital in Curitiba, Paraná, Brazil. J. Bras Patol Med Lab[Internet]. 2016 [cited 2016 Dec 30];52(5):338-44. Available from: http://www.scielo.br/pdf/jbpml/v52n5/1676-2444-jbpml-52-05-0338.pdf 
6. Ferrer APS, Grisi SJFE. Assessment of access to primary health care among children and adolescents hospitalized due to avoidable conditions. Rev Assoc Med Bras[Internet]. 2016 [cited 2016 Nov 30];62(6):513-23. Available from: http://www.scielo.br/pdf/ $\mathrm{ramb/v62n6/0104-4230-ramb-62-6-0513.pdf}$

7. Konstantyner T, Mais LA, Taddei JAAC. Factors associated with avoidable hospitalization of children younger than 2 years old: the 2006 Brazilian National Demographic Health Survey. Int J Equity Health [Internet]. 2015[cited 2016 Oct 30];14:69. Available from: https://www.ncbi.nlm.nih.gov/pmc/articles/PMC4546099/pdf/12939_2015_Article_204.pdf

8. Cecil E, Bottle A, Sharland M, Saxena S. Impact of UK Primary Care Policy Reforms on short-stay unplanned hospital admissions for children with primary care-sensitive conditions. Ann Fam Med [Internet]. 2015[cited 2017 Feb 30];13(3):214-20. Available from: https://www.ncbi.nlm.nih.gov/pmc/articles/PMC4427415/pdf/0130214.pdf

9. Avelino CCV, Goyatá SLT, Nogueira DA, Rodrigues LBB, Siqueira SMS. Quality of primary health care: an analysis of avoidable hospitalizations in a Minas Gerais county, Brazil. Ciênc Saúde Colet[Internet]. 2015[cited 2016 Jan 25];20(4):1285-93. Available from: http://www.scielo.br/pdf/csc/v20n4/1413-8123-csc-20-04-01285.pdf

10. Donabedian A. The seven pillar of quality. Arch Pathol Lab Med. 1990; 114(11):1115-18.

11. Donabedian A. Evaluating the quality of medical care. Milbank Q[Internet]. 2005 [cited 2015 Jun 15];83(4):691-29. Available from: https://www.ncbi.nlm.nih.gov/pmc/articles/PMC2690293/pdf/milq0083-0397.pdf

12. Malouin RA, Starfield B, Sepulveda MJ. Evaluating the tools used to assess the medical home. Manag Care [Internet] 2009[cited 2015 Jun 10]; 18(6):44-8. Available from: http://www.jhsph.edu/research/centers-and-institutes/johns-hopkins-primary-care-policycenter/PCAT\% 20pubs/Malouin \% 202009.pdf

13. Brasil. Ministério da Saúde. Secretaria de Atenção em Saúde. Departamento de Atenção Básica. Manual do instrumento de avaliação da atenção primária à saúde: primary care assessment tool-PCATool - Brasil. Brasília, DF: Ministério da Saúde, 2010.

14. Furtado MC, Braz JC, Pina JC, Mello DF, Lima RAG. Assessing the care of children under one year old in Primary Health Care. Rev Latino-Am Enfermagem [Internet]. 2013 [cited 2015 Nov 25];21(2):554-61. Available from: http://www.scielo.br/pdf/rlae/v21n2/ pt_0104-1169-rlae-21-02-0554.pdf

15. Damasceno SS, Nóbrega VM, Coutinho SED, Reichert APS, Toso BRGO, Collet N. Children's Health in Brazil: orienting basic network to Primary Health Care. Ciênc Saúde Colet[Internet]. 2016 [cited 2017 Mar 10];21(9):2961-73. Available from: http:// www.scielo.br/pdf/csc/v21n9/1413-8123-csc-21-09-2961.pdf

16. Santos NCCB, Toso BRGO, Collet N, Reichert APS. Family-centeredness and community orientation according to three child health care models. Acta Paul Enferm [Internet]. 2016 [cited 2017 Feb 15];29(6):610-7. Available from: http://www.scielo.br/pdf/ ape/v29n6/en_1982-0194-ape-29-06-0610.pdf

17. Silva RMM, Viera CS, Toso BRGO, Neves ET, Rodrigues RM. Problem-solving capacity in children health care: the perception of parents and caregivers. Acta Paul Enferm [Internet]. 2013 [cited 2015 Feb 24];26(4):382-8. Available from: http://www.scielo.br/ pdf/ape/v26n4/en_v26n4a13.pdf

18. Finkler AL, Viera CS, Tacla MTGM, Toso BRGO. The access and the difficulty in resoluteness of the child care in primary health care. Acta Paul Enferm [Internet]. 2014 [cited 2015 May 10];27(6):548-53. Available from: http://www.scielo.br/pdf/ape/ v27n6/1982-0194-ape-027-006-0548.pdf

19. Oliveira VBCA, Veríssimo MLÓR. Assistência à saúde da criança segundo suas famílias: comparação entre modelos de Atenção Primária. Rev Esc Enferm USP [Internet]. 2015 [cited 2017 Oct 20];49(1):30-36. Available from: http://www.scielo.br/pdf/reeusp/ v49n1/pt_0080-6234-reeusp-49-01-0030.pdf

20. Ferrer APS, Brentani AVM, Sucupira ACSL, Navega ACB, Cerqueira ES, Grisi SJFE. The effects of a people-centered model on longitudinality of care and utilization pattern of healthcare services-Brazilian evidence. Health Policy Plan [Internet]. 2014[cited 2015 Nov 20];29(Suppl 2):ii107-ii113. Available from: https://www.ncbi.nlm.nih.gov/pmc/articles/PMC4202922/pdf/czu077.pdf

21. Frank BRB, Viera CS, Ross C, Obregón PL, Toso BRGO. Avaliação da longitudinalidade em unidades de Atenção Primária à Saúde. Saúde Debate [Internet]. 2015 [cited 2016 Jan 21];39(105):400-10. Available from: http://www.scielo.br/pdf/sdeb/v39n105/01031104-sdeb-39-105-00400.pdf

22. Vaz EMC, Magalhães RKBPM, Toso BRGO, Reichert APS, Collet N. Longitudinality in childcare provided through Family Health Strategy. Rev Gaúcha Enferm [Internet]. 2015[cited 2016 Feb 12];36(4):49-54. Available from: http://www.seer.ufrgs.br/index.php/ RevistaGauchadeEnfermagem/article/view/51862/35662

23. Diniz SGM, Damasceno SS, Coutinho SED, Toso BRGO, Collet N. Evaluating comprehensiveness in children's healthcare. Rev Gaúcha Enferm [Internet]. 2016[cited 2017 Mar 19];37(4):e57067. Available from: http://www.scielo.br/pdf/rgenf/v37n4/01026933-rgenf-1983-144720160457067.pdf

24. Souza GT, Alves BA, Tacla MTGM, Collet N, Toso BRGO. Avaliação do princípio da coordenação na atenção primária à saúde da criança em Londrina-PR. Semina: Ciênc Biol Saúde [Internet]. 2015 [cited 2016 Nov 22];36(1):39-46. Available from: http://www. uel.br/revistas/uel/index.php/seminabio/article/view/18420/17289

25. Reichert APS, Leôncio ABA, Toso BRGO, Santos NCCB, Vaz EMC, Collet N. Family and community orientation in children's primary healthcare. Ciênc Saúde Colet[Internet]. 2016 [cited 2017 May 25];21(1):119-27. Available from: http://www.scielo.br/ $\mathrm{pdf} / \mathrm{csc} / \mathrm{v} 21 \mathrm{n} 1 / 1413-8123-\mathrm{csc}-21-01-0119 . \mathrm{pdf}$ 